\title{
$\Psi$
}

\section{THE MOST REV. PASCHAL ROBINSON, O.F.M.}

\author{
Titular Archbishop of Tyana \\ Apostolic Nuncio to Ireland
}

Honorary Member of the Academy of American Franciscan

History and of the American Catholic Historical

Association, Fellow of the Royal Historical

Society of ENGLAND

$1870-1948$

\section{$\mathbf{T}$}

\HE MOST REV. PASCHAL ROBINSON, O.F.M., Apostolic Nuncio to Ireland, died on August 27, 1948, at the Nunciature, Phoenix Park, Dublin. Archbishop Robinson, born in Ireland on April 26, 1870, as a young man came to the United States, where he joined the Franciscan Province of the Holy Name in 1896. For a number of years he taught in the schools of that Province, as well as at the Monastery of the Holy Land in Washington, D. C. In 1913 he was named Professor of Medieval History at the Catholic University, a post he held until his appointment to the diplomatic service of the Holy See in 1919.

Before he was twenty-five, the young Robinson was already well known in journalistic circles, having been London correspondent for The New York Sun. At the age of twenty-two, he became Associate Editor of The North American Review, the outstanding literary vehicle of the time. He was not to find complete satisfaction in this type of life, however, and in 1895 he entered Holy Cross College, Worcester, Mass., as a preliminary step toward priestly studies. The following year he received the Franciscan habit at St. Bonaventure College, St. Bonaventure, N. Y. Recognizing his extraordinary ability, his superiors sent him to complete his theological course at the recently founded International College of the Order in Rome. In that city he was ordained priest in 1901, and received, in 1902, the degree of Lector Generalis. Returning to the United States, he began his teaching career in the same year.

At the same time he commenced the writing in historical subjects which was not only to bring him international distinction but also 
notably to spur the development of historical criticism in the United States. In answer to Paul Sabatier, whose celebrated Vie de S. François, though a brilliant piece of historical investigation, was vitiated by a profound anti-Catholic animus, Father Paschal published in 1904 his The Real Saint Francis. Although it was a slender work, it was written with such penetration and lucidity that it successfully orientated Franciscan studies and research along orthodox lines. It merited the highest encomia from the ranking critics in Europe and America, and was praised by non-Catholic, as well as Catholic, historians for its presentation of the genuine spirit of the Poverello. In subsequent years, Dr. Robinson published The Writings of St. Francis (1906), Some Pages of Franciscan History (1906), A Short Introduction to Franciscan Literature (1907), The Golden Sayings of Brother Giles (1907), and The Life of St. Clare of Assisi (1910). ln the meantime, he was contributing to some of the leading reviews of the day, and he became one of the most valued advisers in the first great undertaking of American Catholic scholarship, the Catbolic Encyclopedia, for which he wrote the principal articles bearing on Franciscan history and interpretation.

In 1904, the Minister General of the Franciscan Order, upon establishing the now-celebrated school of Franciscan research at Quaracchi near Florence, chose Father Paschal as a member of the staff. During this period he visited several archives in central Italy in search of hitherto unknown Franciscan material. In 1907 he became Associate Editor of the Quaracchi college organ, the Arcbivum Franciscanum Historicum. In subsequent years he investigated the archives of the Order in England and Ireland, Germany and Belgium as well as in Italy. He likewise lectured on Franciscan history at Oxford and Dublin Universities.

Back in America in 1913, he was appointed to the Chair of Medieval History at the Catholic University of America in Washington, and, in 1914, the Royal Historical Society of England made him a Fellow.

There began a new chapter in his career in 1919 when he was appointed by the United States Government, together with other distinguished educators from Harvard, Princeton and Columbia, to attend the Peace Conference at Versailles in a special advisory capacity. At the conclusion of this service, the Holy See claimed his talents, sending him on several missions of importance. Meanwhile, the Catholic University, loathe to believe that it had permanently lost one of its outstanding faculty members, declined to name his successor to the Chair of Medieval History. For his part, Father Paschal longed 
to return to the congenial atmosphere of study and research, for he wrote from Rome, in 1920, to Dr. Bernard McKenna, one of his closest friends and colleagues at the Catholic University, "I look forward to returning to the United States without fail during the vacation, i. e., before mid-September, and I only regret that my sojourn has been so much prolonged." However, other and increasingly important missions were confided to him by the Holy See. In recognition of his outstanding services, he was, in 1927, consecrated Titular Archbishop of Tyana. In 1929 he discharged a very delicate assignment to the Island of Malta, and in the fall of that year, he was appointed Apostolic Nuncio to Ireland-a post calling for the utmost tact and the most impeccable diplomacy. After his appointment, he wrote to his friend, Dr. McKenna, referring to "the new and arduous task which the Holy See, in spite of my extreme reluctance, has imposed upon me just as I was beginning to hope for a little much-needed rest in some congenial solitude."

The historian in him was never again to have the opportunity to satisfy his bent: thereafter, as for many years previously, the duties of his high office precluded those literary and historical pursuits to which, from his youth, he had been dedicated. Yet his interest in historical movements and matters never waned. In 1942, in view of his contributions of an earlier day to historical science, he was made an Honorary Member of the American Catholic Historical Association, and he wrote that he was highly honored with the tribute.

From its beginning, Archbishop Robinson displayed the doubly keen interest of a Franciscan and a historian in the work of the Academy of American Franciscan History. When it was founded in 1944, he was immediately made an Honorary Member. He sent at that time the following letter to the Director:

Apostolic Nunciature,

Phoenix Park, Dublin, Eire,

Dear Fr. Director,

May 2, 1944.

I greatly appreciate your thoughtful courtesy in writing to inform me of the founding of the Academy of American Franciscan History, and I need hardly say that I have learned of this new undertaking with quite unusual interest and pleasure. Moreover, I take it as a high compliment that the Fathers of the Academy should wish me to become one of its Honorary Members, and I value this remembrance the more because it comes to me on the fortieth anniversary of the publication of my first modest contribution to the history of our holy Order. 
I fear that in the present circumstances I cannot be of much service to the Academy here, but I am always at your disposal if, at any time, you think I can be of assistance to you in your work.

Meanwhile, I can only send you and your associates my congratulations and best wishes, and this I do most heartily.

Fraternally and gladly yours,

+ Fr. Paschal Robinson, O.F.M.

That treasured communication seems to summarize, in many ways, the place of Archbishop Paschal Robinson in the evolution of historical studies in the United States. The pioneer who, forty years ago, helped to plant the seed of historical research, which is responsible for the present-day flowering of historical pursuits in the Church of the United States, remained, despite the high honors and attainments which were his, a Franciscan devoted to his "holy Order" with whose history and spirit he was so conversant. His friend Monsignor McKenna has written that "his humility and wisdom made him a true son of St. Francis. . . I I learned from him many lessons of the devotion of St. Francis and other Franciscan Saints to the Blessed Virgin."

His obsequies, at his express will, were not those of the Dean of Dublin's Diplomatic Corps, nor those of an Archbishop: Father Paschal Robinson was laid, brown-habited and barefoot, in the ground beside his brothers in St. Francis.

May the gentle soul of this devoted Franciscan historian rest in peace!

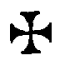

